\title{
Political and Economic Impacts of Refugees: Some Observations on Mozambican Refugees in Malawi
}

\author{
Lewis B. Dzimbiri
}

\section{Introduction}

In recent years, numbers of refugees and migrants have reached crisis levels as the causes of flight have multiplied: wars, infringements of civil liberties, economic problems, environmental catastrophes, and increasing population pressures, to name a few. Whatever the cause of flight, the hosting of large influxes of refugees by a country of first asylum raises deep-rooted political and economical issues related to the obligations and the capacities of poor asylum countries. This paper attempts to examine some of the issues that emerge as both positive and negative impacts in a host country based on the experience of Malawi-a country that has managed to host nearly a million Mozambican refugees over the past six years or so.

The refugee phenomenon is an enormous international problem. Since the end of the second world war, the world has never seen a single day of peace. Wars, human rights violations, civil conflicts, tribal and religious repression, frontier disputes, interstate conflicts, and economic crises, to name a few, are viewed as some of the causes of flight from homeland (Meier-Braun 1992). The International Labour Organisation estimates that, worldwide, more than 100 million individuals have left their native land and now earn a living in a foreign country. About 35 million Africans no longer live in the country of their birth.

\section{The Context of the Refugees in Malawi}

Refugees from Mozambique have been entering Malawi since 1985, however, the main influx started in 1986. In

Lewis B. Dzimbiri is an associate professor at Chancellor College, University of Malawi, Zomba, Malawi. early 1988 the refugee flow averaged 20,000 a month. To date, the refugee population is estimated at almost one million. The vast majority of the refugees live in the densely populated southern region in Malawi. Twelve out of the twenty-four districts of Malawi host refugees, either in camps or selfsettled areas. Table 1 shows the population of refugees in Malawi, and represents 12 percent of the population of the whole country.

Refugee assistance is administered as a collaborative effort between the Government of Malawi (GOM), various nongovernmental organizations (NGOs) and the UNHCR-United Nations High Commissioner for Refugees. In brief, Malawi has adopted a policy of integrating the administration of humanitarian assistance into existing government ministries, rather than creating a parallel bureaucratic structure which would compete for resources and duplicate government activities. At the camp or settlement level, there exists an informal structure for refugee representation alongside the formal government structure. The ensuing superstructure is complex and its modus operandi is the dynamic interaction between the formal and informal administrative structures. An elaborate procedure exists, from reception, registration and allocation of plots, to the distribution of relief, problem management and the involvement of refugees in various income-generating activities.

\section{Positive Economic and Political Impacts}

In any discussion of refugee-related impacts on host countries, one expects both positive and negative aspects. Four positive impacts will be discussed here: employment creation, accrual of benefits to the local population, the stimulation of local commerce and an improved international image.

\section{Creation of Employment}

Creation of employment opportunities for the Malawian nationals amid alarming unemployment figures is a significant outcome of humanitarian assistance. At the national level, we are referring to the many temporary employees recruited to staff our overstretched national bureaucracy to reach the refugee population. Local Malawians are hired as medical assistants, camp administrators, relief administrators, watchmen, project supervisors, extension staff, drivers, etc. In a study conducted by the writer on organization and management of the refugee regime in Malawi, it was estimated that over 600 individuals were employed full time by the relief program in Nsanje district alone (Dzimbiri 1992).

Involvement of nationals in government ministries and non-government organizations, not only provides direct economic benefits, it is also conducive to developing human resources and strengthening the national and local capacity to administer relief programs and respond to national crises. Furthermore, employment benefits need to be looked at from the perspective of the employer. In areas where there have traditionally been seasonal shortages of casual labour, the influx of refugees has created a cheap and accessible labour force for both the smallholder and estate agricultural sectors, although this is thought to depress local wages as a result (Long et al. 1990).

\section{Accrual of Benefits}

NGOs provide many relief inputs and services such as schools, boreholes, 
health clinics, income generation projects, etc. While initially targeted toward the refugees, the present policy of most of these organizations is to incorporate a significant number of Malawians as beneficiaries of various services and income generating activities (Machika 1992; Dzimbiri 1992). As a result, local people have benefited from clean drinking water from new boreholes and expanded health services from new clinics built in the refugee areas.

\section{Stimulation of Local Commerce}

The influx of huge numbers of people concentrated within small areas of land has the effect of stimulating local demand for consumable and non-consumable items. Within and around settlement areas and camps, small businesses are thriving. These include restaurants, groceries, shops and tea rooms. Also, there are increased sales of fish, secondhand clothing, handicrafts, and traditional herbs and medicines. Services such as tailoring, and bicycle and shoe repair are also examples of expanding small enterprise. A study by Long et al. (1990) confirmed an increase in the volume of trade in Nsanje district, with a consequent increase in market tickets from 15,349 in $1987 / 88$, to 36,604 in $1989 / 90$.
In addition, there is a tendency among refugees to market some of their relief items such as oil, flour, pulses and blankets at very low prices to the local population. Finally, the services of local transporters have been in high demand to deliver food and non-food items from the main warehouses to refugee sites.

\section{Improved International Image}

The hosting of one million refugees by a small developing country has earned Malawi an international reputation as a generous and hospitable host. Among others, the UN High Commissioner for Refugees, Sadako Ogata, has publicly commended the generosity of the Malawian people and government in hosting the refugees.

Apart from the national political implications of this image raising, there are increased opportunities to access international assistance. The recent unfreezing of development aid funds from the EC is due in part to this positive international image. Despite persistent criticism of Malawi's human rights record, its reputation as a host for more than one million refugees cannot be wished away.

Having briefly discussed one side of the refugee-host coin, the positive impacts, we can now turn our attention to

\begin{tabular}{|c|c|c|c|c|c|c|}
\hline District & 1988 & 1989 & 1990 & 1991 & 1992 & $1993^{*}$ \\
\hline Nsanje & 214,298 & 259,981 & 276,556 & 291,769 & 291,518 & 307,137 \\
\hline Chikwawa & 25,827 & 49,136 & 68,336 & 87,269 & 88,188 & 79,050 \\
\hline Mulanje & 35,180 & 46,968 & 47,493 & 51,792 & 51,054 & 54,938 \\
\hline Mangochi & 26,399 & 34,700 & 38,918 & 44,965 & 44,516 & 38,419 \\
\hline Thyolo & 0 & 22,000 & 34,305 & 40,462 & 40,033 & 16,998 \\
\hline Mwanza & 20,323 & 35,139 & 48,652 & 83,167 & 93,817 & 90,492 \\
\hline Machinga & 13,985 & 17,753 & 22,873 & 27,303 & 27,497 & - \\
\hline Ntcheu & 132,491 & 152,102 & 160,374 & 138,739 & 137,062 & 132,176 \\
\hline Dedza & 113,000 & 160,141 & 174,544 & 153,059 & 155,303 & 138,137 \\
\hline Lilongwe & 20,327 & 31,228 & 35,576 & 38,499 & 38,636 & 26,568 \\
\hline Mchinji & 4,400 & 9,858 & 16,563 & 20,251 & 18,668 & 18,612 \\
\hline Nkhata Bay & 0 & 2,997 & 2,535 & 5,267 & 4,463 & 2,940 \\
\hline Total & 606,230 & 822,003 & 926,725 & 982,542 & 990,755 & 905,467 \\
\hline
\end{tabular}

the negative aspects of hosting a large refugee population.

\section{Negative Socioeconomic and Political Impacts}

Under this subject we will confine ourselves to a discussion of environmental damage, the strain on resources, strained Malawi-Mozambique relations, decreasing national security, the loss of national autonomy and the dilemma of assisting refugees while ignoring local, disadvantaged Malawians.

\section{Environmental Damage}

The environmental damage caused by huge numbers of refugees in Malawi in relation to land, roads and deforestation has been extensively documented by USAID/Malawi (Long at el. 1990), and need not be repeated here. Briefly, a lot of arable land has been surrendered by the local population for refugee camps or settlement areas. Although the opportunity cost of the loss of this agricultural land cannot be precisely quantified, it remains quite substantial.

Forests are a valuable source of construction poles for houses and latrines, firewood, medicine, thatching and fodder. In terms of fuelwood alone it has been estimated that displaced Mozambicans consume between $54,000 \mathrm{MT}$ and $74,000 \mathrm{MT}$ of fuelwood annually (GOM 1992).

The frequent use of heavy trucks transporting food relief to the refugee areas continues to degrade roads. While some of the cost of maintenance is borne by UNHCR, the biggest portion is borne by the Malawi Government. For instance in $1989 / 90$, the total expenditure by the Roads Department was US\$ 4.2 million. The UNHCR contributed US\$ 1.2 million with the rest being borne by the Government of Malawi (GOM 1992:27).

\section{Strain on Resources and Revenues}

The presence of large numbers of refugees in Malawi has placed an enormous strain on the country's economy. In terms of manpower, it has already been pointed out that the administra- 
tion of the relief program has been integrated into the existing government structure. This implies that all government departments and ministries involved-the Office of the President and Cabinet, district administration, health, education, women, children and community services, works, agriculture, and forestry-have to somehow double their workload with the same amount of human resources.

A lot of time and effort by both headquarters and district level officials are spent planning and implementing refugee-related programs. Financially, the cost of allowances, vehicle maintenance and staff salaries in all ministries is a significant expense to the Malawian state. Although partially financed by the UNHCR, a sector expenditure sheet on displaced persons for 1990 alone showed a net total additional cost to the Malawi Government of US\$ 25.1 million (GOM 1992).

It is estimated that 60 to 70 percent of patients in district hospitals are refugees, resulting in a heavy burden on the personnel and facilities. The direct and indirect costs of hosting the refugees, i.e., pressure on public goods and services, has far-reaching consequences for the country. A joint Government of Malawi, World Bank, UNDP and UNHCR report (1990) found that:

The influx of Mozambican refugees into Malawi in 1987-90 has created significant stress on the economy and is beginning to undermine the country's development program and structural adjustment initiatives.

This impact is not peculiar to Malawi. In fact, the impact of the Mozambican war on the rest of the southern African countries is even more alarming. The Commonwealth estimates that the total economic cost of destabilisation to the front-line states is in excess of US $\$ 45$ billion-more than double their external debt.

\section{Strained Malawi-Mozambique Relations}

Since hosting the refugees, Malawi has had increasingly poor relations with Mozambique, fuelled by numerous al- legations by the Mozambican Government. For instance, Malawi was accused of swelling its coffers with international aid by discouraging thousands of Mozambican refugees from returning home; and also, that the Government of Malawi exaggerates the number of Mozambican refugees in order to persuade the international community to provide more money. ${ }^{1}$ The Government of Malawi has consistently refuted such allegations.

\section{Decreased National Security and Rising Security Costs}

Over the past five to ten years, Malawi has experienced decreased security as criminal and military elements have brought AK-47s into the country. As the UNHCR Deputy Representative in Malawi lamented:

Unfortunately there have been several incidents over the past four or five months resulting in both Mozambican and Malawian casualties... these attacks, as far as we can tell, are part of the escalation of the war across the border.

Of late, gunmen have shot dead businessmen in Ntcheu (1992), killed four in Ntcheu/Dedza, and robbed the $\mathrm{Na}$ tional Bank in Blantyre and other organizations. ${ }^{2}$ The consequences of these activities have been increased insecurity, psychological torture to the Malawian people in the border areas, and heavy costs in terms of police investigations and increased patrols.

\section{Loss of Autonomy}

The refugee situation places a host country in a situation in which it has to surrender some of its autonomy in accordance with international standards. For instance, would Malawi enact a Refugee Act without the present refugee crisis in the country? Furthermore, the operation of the humanitarian assistance program may conflict with national development priorities. A lot of actors and interests are involved in decision-making, from the highest national Joint Operations Committee, down to the District Joint Operations Committee and the Camp
Management Committee. As a result, the actual implementation of refugee policy may not mirror the exact nature of national development policies and priorities. To what extent, for example, does the sacrifice the District Commissioner makes in terms of time and effort to attend to refugee related issues, such as the planning of African Refugee Day, among others, reflect the official priorities, needs and requirements of the host nation? Scarce human resources have to be delegated to such activities to appease the international donor community, at the expense of more important responsibilities.

Another example of lost autonomy came from the local population who gave up large portions of their land for the siting of refugee camps. They remain uncompensated and do not have access to relief programs. Mere sacrifice and their precarious situation is not a sufficient index of suffering. Unfortunately, the legal determination of refugee status is irrelevant to local villagers who only see a reallocation of national and international resources to a foreign population. Feeding a refugee population, when up to 55 percent of the local population is malnourished, would not seem to reflect the interests of the host nation.

Perhaps, these contradictions could best be explained in terms of imposed policy agendas. As Bach (1988) observed, inequality in the international order makes African host states incapable of being autonomous in formulating refugee policies. In order to gain access to international development and relief funds, the Malawi Government has had to sacrifice services and funds that were previously allocated to its own population.

\section{Conclusion}

This paper examined some of the socio-economic and political impacts of refugees in a host country with particular reference to Mozambican refugees in Malawi. The major thrust of the paper was that the costs of hosting a refugee population-for small, economically undeveloped countries like Malawi-far outweigh the 